data collection and J. Fonseca (Biostatistics and Medical Informatics, Faculty of Medicine, University of Porto and Immuno-allergology, Hospital of São João, Porto, Portugal) for manuscript revision.

\section{REFERENCES}

1 Helenius I, Haahtela T. Allergy and asthma in elite summer sport athletes. J Allergy Clin Immunol 2000; 106: 444-452.

2 Helenius IJ, Tikkanen HO, Sarna S, Haahtela T. Asthma and increased bronchial responsiveness in elite athletes: atopy and sport event as risk factors. J Allergy Clin Immunol 1998; 101: 646-652.

3 Helenius IJ, Rytilä P, Metso T, Haahtela T, Venge P, Tikkanen HO. Respiratory symptoms, bronchial responsiveness, and cellular characteristics of induced sputum in elite swimmers. Allergy 1998; 53: 346-352.

4 Piacentini GL, Rigotti E, Bodini A, Peroni D, Boner AL. Airway inflammation in elite swimmers. J Allergy Clin Immunol 2007; 119: 1559-1560.

5 Rytilä P, Pelkonen AS, Metso T, Nikander K, Haahtela T, Turpeinen $\mathrm{M}$. Induced sputum in children with newly diagnosed mild asthma: the effect of 6 months of treatment with budesonide or disodium cromoglycate. Allergy 2004; 59: 839-844.

6 American Thoracic Society, European Respiratory Society. ATS/ERS recommendations for standardized procedures for the online and offline measurement of exhaled lower respiratory nitric oxide and nasal nitric oxide, 2005. Am J Respir Crit Care Med 2005; 171: 912-930.

7 Sterk PJ, Fabbri LM, Quanjer PhH, et al. Airway responsiveness. Standardized challenge testing with pharmacological, physical and sensitizing stimuli in adults. Report Working Party Standardization of Lung Function Tests, European Community for Steel and Coal. Official Statement of the European Respiratory Society. Eur Respir J 1993; 6: Suppl. 16, 53-83.

8 Bonetto G, Corradi M, Carraro S, et al. Longitudinal monitoring of lung injury in children after acute chlorine exposure in a swimming pool. Am J Respir Crit Care Med 2006; 174: 545-549.

\title{
Idiopathic pulmonary fibrosis and nonspecific interstitial pneumonia should stay separate
}

\section{To the Editors:}

We read with interest the recent perspective by MAHER et al. [1], challenging the current definition of idiopathic pulmonary fibrosis (IPF). Questioning dogma is critical to progress in science and the authors should be commended for doing so.

We agree that the relationship between disease entity (i.e. clinical diagnosis) and histopathological pattern is more complex than simply equating IPF with usual interstitial pneumonia (UIP), and that distinguishing idiopathic UIP from idiopathic nonspecific interstitial pneumonia (NSIP) can sometimes be difficult, even for expert clinicians, radiologists and pathologists [2]. Indeed, the American Thoracic Society/ European Respiratory Society Consensus Statement made these points quite deliberately [3].

However, we disagree with the authors' contention that "idiopathic UIP and idiopathic NSIP, sharing a common clinical phenotype, form a spectrum of disease with a common pathogenesis" [1]. This blanket statement assumes a homogeneity to idiopathic NSIP and idiopathic UIP that is contrary to the evidence. The idea of a distinct clinical phenotype for idiopathic NSIP is supported by demographic, serological and survival differences seen when IPF and idiopathic NSIP patients are compared [4-6], and by the differences, not similarities, seen in gene expression profiles (six of 10 published NSIP profiles are distinct from UIP while four are similar) $[7,8]$.
It is our belief that idiopathic nonspecific interstitial pneumonia represents a collection of conditions including occult connective tissue disease, hypersensitivity pneumonia and, perhaps, truly idiopathic cases, and should not be lumped together clinically with idiopathic pulmonary fibrosis. We share the hope of MAHER et al. [1] that new and emerging methods of categorising disease will allow us to better understand the relationship of histopathology to pathogenesis and to refine future definitions and diagnostic criteria.

\section{H.R. Collard and T.E. King Jr}

Dept of Medicine, University of California, San Francisco, CA, USA.

\section{STATEMENT OF INTEREST}

None declared.

\section{REFERENCES}

1 Maher TM, Wells AU, Laurent GJ. Idiopathic pulmonary fibrosis: multiple causes and multiple mechanisms? Eur Respir J 2007; 30: 835-839.

2 Flaherty KR, King TE Jr, Raghu G, et al. Idiopathic interstitial pneumonia: what is the effect of a multidisciplinary approach to diagnosis? Am J Respir Crit Care Med 2004; 170: 904-910. 
3 American Thoracic Society. Idiopathic pulmonary fibrosis: diagnosis and treatment. International consensus statement. American Thoracic Society (ATS), and the European Respiratory Society (ERS). Am J Respir Crit Care Med 2000; 161: 646-664.

4 Kinder BW, Collard HR, Koth L, et al. Idiopathic nonspecific interstitial pneumonia: lung manifestation of undifferentiated connective tissue disease? Am J Respir Crit Care Med 2007; 176: 691-697.

5 Daniil ZD, Gilchrist FC, Nicholson AG, et al. A histologic pattern of nonspecific interstitial pneumonia is associated with a better prognosis than usual interstitial pneumonia in patients with cryptogenic fibrosing alveolitis. Am J Respir Crit Care Med 1999; 160: 899-905.

6 Bjoraker JA, Ryu JH, Edwin MK, et al. Prognostic significance of histopathologic subsets in idiopathic pulmonary fibrosis. Am J Respir Crit Care Med 1998; 157: 199-203.

7 Selman M, Pardo A, Barrera L, et al. Gene expression profiles distinguish idiopathic pulmonary fibrosis from hypersensitivity pneumonitis. Am J Respir Crit Care Med 2006; 173: 188-198.

8 Yang IV, Burch LH, Steele MP, et al. Gene expression profiling of familial and sporadic interstitial pneumonia. Am J Respir Crit Care Med 2007; 175: 45-54.

DOI: $10.1183 / 09031936.00168607$

\section{From the authors:}

We appreciate the comments of H.E. Collard and T.E. King on our article [1]. The American Thoracic Society (ATS)/European Respiratory Society (ERS) consensus classification has been important in advancing clinical understanding of the idiopathic interstitial pneumonias [2]. In that document, the clinical entity of nonspecific interstitial pneumonia (NSIP) was proposed as a provisional term only. As we have argued, we believe that using histological appearances alone to define separate clinical entities is unhelpful [1]. Different histological patterns may occur in the same patient [3]. Furthermore, conditions with a defined aetiology (e.g. hypersensitivity pneumonitis, connective tissue disease or familial pulmonary fibrosis) may give rise to either usual interstitial pneumonia (UIP) or NSIP in different patients [4-6].

By associating the histological lesion of NSIP with a clinical diagnosis of NSIP, the ATS/ERS consensus classification has blurred the distinction between idiopathic and secondary NSIP in the minds of many clinicians. This has led some to consider NSIP as a single disorder. We agree strongly with H.E. Collard and T.E. King that many cases of NSIP are due to either connective tissue disease or hypersensitivity pneumonitis. However, when reviewing the clinical data in such cases there are often ancillary features that point to the underlying diagnosis [7]. Once secondary cases are excluded, there remains a large subgroup of NSIP patients who have a clinical phenotype that overlaps substantially with that of UIP/idiopathic pulmonary fibrosis (IPF). This group of patients have a sex distribution, smoking-exposure history, mode of clinical presentation, distribution of clinical signs and bronchoalveolar lavage cell differential that mirrors that of IPF/UIP $[2,8,9]$. The distribution of disease on high-resolution computed tomography is also strikingly similar [10].

We therefore propose that idiopathic UIP and idiopathic NSIP, sharing a common clinical phenotype, form a spectrum of disease with a common pathogenesis. The pathogenetic mechanisms involved in the development and progression of IPF are complex and are likely to involve abnormalities in a number of the multiple pathways of normal wound healing [1]. It seems likely that the balance of abnormalities in each of the key wound-healing pathways may vary between individuals. This variation is likely to be responsible for the range of clinical, radiological and pathological phenotypes observed in IPF.

Like H.E. Collard and T.E. King, we hope that future clinical and scientific research will further clarify these issues, as advances in our understanding of idiopathic pulmonary fibrosis can only be to the benefit of patients with this devastating and currently untreatable disease.

\section{T.M. Maher* ${ }^{*}$, A.U. Wells ${ }^{\#}$ and G.J. Laurent ${ }^{*}$}

*Centre for Respiratory Research, Rayne Institute, University College London, and "Interstitial Lung Disease Unit, Royal Brompton Hospital, London, UK.

\section{STATEMENT OF INTEREST}

None declared.

\section{REFERENCES}

1 Maher TM, Wells AU, Laurent GJ. Idiopathic pulmonary fibrosis: multiple causes and multiple mechanisms? Eur Respir J 2007; 30: 835-839.

2 American Thoracic Society, European Respiratory Society. American Thoracic Society/European Respiratory Society International Multidisciplinary Consensus Classification of the Idiopathic Interstitial Pneumonias. Am J Respir Crit Care Med 2002; 165: 277-304.

3 Monaghan H, Wells AU, Colby TV, du Bois RM, Hansell DM, Nicholson AG. Prognostic implications of histologic patterns in multiple surgical lung biopsies from patients with idiopathic interstitial pneumonias. Chest 2004; 125: 522-526.

4 Ohtani Y, Saiki S, Kitaichi M, et al. Chronic bird fancier's lung: histopathological and clinical correlation. An application of the 2002 ATS/ERS consensus classification of the idiopathic interstitial pneumonias. Thorax 2005; 60: 665-671.

5 Rosas IO, Ren P, Avila NA, et al. Early interstitial lung disease in familial pulmonary fibrosis. Am J Respir Crit Care Med 2007; 176: 698-705.

6 Park JH, Kim DS, Park IN, et al. Prognosis of fibrotic interstitial pneumonia: idiopathic versus collagen vascular disease-related subtypes. Am J Respir Crit Care Med 2007; 175: 705-711.

7 Kinder BW, Collard HR, Koth L, et al. Idiopathic nonspecific interstitial pneumonia: lung manifestation of undifferentiated connective tissue disease? Am J Respir Crit Care Med 2007; 176: 691-697. 